\title{
In vitro inhibition of the bovine viral diarrhoea virus by the essential oil of Ocimum basilicum (basil) and monoterpenes
}

\author{
Thaís F. Kubiça ${ }^{1}$, Sydney H. Alves ${ }^{1}$, Rudi Weiblen ${ }^{2}$, Luciane T. Lovato ${ }^{1}$ \\ ${ }^{1}$ Departamento de Microbiologia e Parasitologia, Universidade Federal de Santa Maria, \\ Santa Maria, RS, Brazil. \\ ${ }^{2}$ Departamento de Medicina Veterinária Preventiva, Universidade Federal de Santa Maria, \\ Santa Maria, RS, Brazil.
}

Submitted: December 4, 2012; Approved: September 9, 2013.

\begin{abstract}
The bovine viral diarrhoea virus (BVDV) is suggested as a model for antiviral studies of the hepatitis $\mathrm{C}$ virus (HCV). The antiviral activity of the essential oil of Ocimum basilicum and the monoterpenes camphor, thymol and 1,8-cineole against BVDV was investigated. The cytotoxicities of the compounds were measured by the MTT (3-(4.5-dimethylthiazol-2-yl)-2.5-diphenyltetrazolium bromide) test, and the antiviral activities were tested by the plaque reduction assay. The oil or compounds were added to the assay in three different time points: a) pre-treatment of the virus (virucidal assay); b) pre-treatment of the cells; or c) post-treatment of the cells (after virus inoculation). The percentage of plaques inhibition for each compound was determined based on the number of plaques in the viral control. The results were expressed by $\mathrm{CC}_{50}\left(50 \%\right.$ cytotoxic concentration), $\mathrm{IC}_{50}$ (inhibitory concentration for $50 \%$ of plaques) and SI (selectivity index $\left.=\mathrm{CC}_{50} / \mathrm{IC}_{50}\right)$. Camphor $\left(\mathrm{CC}_{50}=4420.12 \mu \mathrm{g} \mathrm{mL}^{-1}\right)$ and 1,8-cineole $\left(\mathrm{CC}_{50}=2996.10 \mu \mathrm{g} \mathrm{mL}^{-1}\right)$ showed the lowest cytotoxicities and the best antiviral activities (camphor SI $=13.88$ and 1,8-cineol $\mathrm{SI}=9.05$ ) in the virucidal assay. The higher activities achieved by the monoterpenes in the virucidal assay suggest that these compounds act directly on the viral particle.
\end{abstract}

Key words: antiviral, camphor, 1.8-cineol, thymol.

\section{Introduction}

The bovine viral diarrhoea virus (BVDV), the prototype of the genus Pestivirus in the Flaviviridae family, is responsible for several clinical manifestations in bovines, including respiratory, gastroenteric and reproductive diseases (Thiel et al., 1996). The BVDV is regarded as a model for the hepatitis $\mathrm{C}$ virus (HCV) due to similarities in the virion structures, genome organisations and replication cycles (Buckwold et al., 2003). This knowledge has been applied to antiviral studies in vitro because the HCV does not replicate efficiently in cell cultures (Bhattacharyya et al., 2003; Buckwold et al., 2003; Yanagida et al., 2004; Romero et al., 2006; Zhang et al., 2010).

The HCV, the only member of the Hepacivirus genus, is the most common cause of chronic hepatitis throughout the world and the main risk factor for cirrhosis and hepatocellular carcinoma (Liang et al., 2000). It is estimated worldwide that approximately 150 million people live with a chronic $\mathrm{HCV}$ infection and that more than 350,000 patients die each year from liver disease associated with the infection (WHO, 2012). A vaccine is not available for the $\mathrm{HCV}$ infection, and the treatment is primarily based on a combination drug therapy with interferon- $\alpha$ (IFN- $\alpha$ ) and ribavirin (Bhattacharyya et al., 2003). However, this type of therapy is expensive and induces several side effects due to high drug toxicity (Bhattacharyya et al., 2003; Yanagida et al., 2004). Thus, new therapeutic options for the treatment of $\mathrm{HCV}$ infections are needed.

Natural products obtained from plants have provided the pharmaceutical industry with a great resource for new therapeutic drugs. Approximately $40 \%$ of modern medi- 
cines originate from compounds present in natural products that are either extracted from nature or synthesised (Jassim and Naji, 2003). A wide variety of active phytochemicals, including terpenes, terpenoids, aliphatics and aromatics, have been identified as responsible for the biological activities of the natural products (Bakkali et al., 2008). Volatile essential oils, commonly used as food condiments, have exhibited high levels of antiviral activity (Astani et al., 2010; Pilau et al., 2011); however, only a few of these compounds have been examined (Jassim and Naji, 2003).

Essential oils constitute a diverse set of compounds that vary in concentrations (Astani et al., 2010). Monoterpenes are the major components of essential oils, constituting $90 \%$ of these oils (Bakkali et al., 2008). The monoterpenes 1,8-cineole, camphor and thymol are found in different concentrations among plants (e.g., Ocimum basilicum (basil), Rosmarinus officinalis (rosemary) and Thymus vulgaris (thyme)) commonly used in gastronomy and traditional medicine (Lee et al., 2005; Pozzatti et al., 2008). The monoterpenes 1,8-cineole and thymol have previously been shown to display antiviral activities against the herpes simplex virus (HSV) in vitro (Astani et al., 2010).

Ocimum basilicum L., commonly known as basil, is a plant of the family Lamiaceae, which is largely utilised as a cooking herb and which has been applied in traditional medicine for the treatment of assorted diseases, including gastric and respiratory disorders (Sartoratto et al., 2004; Chiang et al., 2005). The potential activities of basil against bacteria (Suppakul et al., 2003; Sartoratto et al., 2004), fungi (Pozzatti et al., 2008) and viruses (Chiang et al., 2005 ) have been investigated. The chemical composition of the basil plant essential oil includes thymol, methyl-chavicol, linalool, eugenol, 1,8-cineole and pirene (Suppakul et al., 2003; Sartoratto et al., 2004; Chiang et al., 2005; Pozzatti et al., 2008) and the composition may vary in quality and quantity.

The present study was conducted to test the antiviral activities of the essential oil of Ocimum basilicum (basil) and its constituent compounds 1,8-cineole, camphor and thymol against BVDV in different time points of the infection.

\section{Materials and Methods}

\section{Essential oils and monoterpenes}

The procedures for obtaining the plant samples (Ocimum basilicum), essential oil extraction and analyses of the chemical constituents were previously reported (Pozzatti et al., 2008). The qualitative and semiquantitative analyses of the chemical constituents of basil were performed using the techniques of gas chromatography (GC) and gas chromatography coupled with mass spectrometry (GC-MS), which yielded the mass spectra of most essential oil components (Pozzatti et al., 2008). The compounds 1,8-cineole, camphor and thymol were purchased commercially (Acros Organics, Belgium).

To perform the activity tests, the essential oil of basil and the monoterpenes were first diluted in methanol to a concentration of $0.64 \mathrm{~g} \mathrm{~mL}^{-1}$ (solution I). Solution I was then diluted to $1: 100$ in minimal essential medium (MEM) to a final concentration of $6400 \mu \mathrm{g} \mathrm{mL}^{-1}$ (solution II). Solution II was used as the working dilution in the cytotoxicity and antiviral activity tests.

\section{Cell culture and viruses}

Madin-Darby bovine kidney cells (MDBK) were maintained in MEM with 10\% equine serum (ES) and penicillin, streptomycin and amphotericin $\mathrm{B}$ at the concentrations of $100 \mathrm{U} \mathrm{mL}^{-1}, 100 \mu \mathrm{g} \mathrm{mL} L^{-1}$ and $2.5 \mu \mathrm{g} \mathrm{mL}^{-1}$, respectively. Cell cultures were incubated at $37{ }^{\circ} \mathrm{C}$ with an atmosphere of $5 \% \mathrm{CO}_{2}$. The cytotoxicity and antiviral activity tests were performed in 96 well- and 6 well-plates, respectively.

The bovine viral diarrhoea virus (BVDV) cytopathic strain Singer, genotype 1 was provided by the Setor de Virologia of the Universidade Federal de Santa Maria (UFSM). The virus stocks were prepared and titrated as previously described (Botton et al., 1998), and aliquots were kept at $-70{ }^{\circ} \mathrm{C}$ until use.

\section{Cytotoxicity assay}

The cytotoxicities of the essential oil of $O$. basilicum and the monoterpenes were measured by the MTT (3-(4,5dimethylthiazol-2-yl)-2,5-diphenyltetrazolium bromide) colorimetric assay (M2128, Sigma-Aldrich, Inc, St. Louis, MO, USA), according to the methodology described by Mosmann (1983) and modified by Cueto et al. (2011).

Briefly, MEM and increasing concentrations (25 to $3200 \mu \mathrm{g} \mathrm{mL}^{-1}$ ) of the essential oil or compounds were added to the preformed cell monolayer $\left(1.6 \times 10^{5}\right.$ cells $\mathrm{mL}^{-1}$ ) in 96-well plates (NUNC, Roskilde, Denmark) for a total of 6 replicates for each concentration. Control wells for cells only and methanol toxicity were included. After $72 \mathrm{~h}$ of incubation at $37{ }^{\circ} \mathrm{C}$ and $5 \% \mathrm{CO}_{2}$, the medium was removed, $50 \mu \mathrm{L}$ of MTT $\left(1 \mathrm{mg} \mathrm{mL}^{-1}\right)$ was added to the plates and the plates incubated at the same conditions for an additional period of $2 \mathrm{~h}$. After the removal of the MTT, $100 \mu \mathrm{L}$ of dimethyl sulfoxide (DMSO) was added to solubilise the formazan crystals. The supernatant was then transferred to a new plate, and the absorbancies were read on a spectrophotometer at $540 \mathrm{~nm}$.

The cell viability was calculated according to the formula: absorbance of the compound or essential oil/absorbance of the cell control x 100\%. The concentration-effect curve was obtained by a linear regression analysis using data from three independent experiments performed in duplicate. The concentration of the compound that reduced cell viability by $50 \%$ was defined as the $50 \%$ cytotoxic concentration $\left(\mathrm{CC}_{50}\right)$. The highest concentration of the com- 
pound that did not cause cytotoxicity (maximum non-toxic concentration $=$ MNTC) was subsequently used in the tests for antiviral activity.

\section{Antiviral assay}

The antiviral activities for each compound were measured by a plaque reduction assay. Three different assays were performed to elucidate the mechanisms of action for the oil and the monoterpenes. Treatment with the essential oil or monoterpenes was applied at different time points: a) pre-treatment of the virus (virucidal assay); b) pre-treatment of the cells; or c) post-treatment of the cells, as described by Astani et al. (2010) with some modifications.

The virucidal assay was performed with a constant volume of a virus suspension (BVDV) and varying concentrations of the essential oil or monoterpenes, and the mixtures were incubated in microcentrifuge tubes for $1 \mathrm{~h}$ at room temperature. Following the incubation period, aliquots of each mixture were inoculated into the cells and viral adsorption was allowed to proceed for $2 \mathrm{~h}$ at $37^{\circ} \mathrm{C}$ $\left(10^{3} \mathrm{PFU}\right)$. The residual inoculum was removed, and the infected cells were then overlaid with $2 \mathrm{~mL}$ of MEM containing $0.5 \%$ agarose and $5 \%$ equine serum. The plates were incubated for $72 \mathrm{~h}$ at $37^{\circ} \mathrm{C}$, followed by fixation and staining with formaldehyde and crystal violet for $1 \mathrm{~h}$ at room temperature. Finally, the crystal violet was removed and plaque counting was performed. The percentage of virus inhibition for each concentration of a compound was calculated based on the plaque counts observed in treated cells compared to the virus control monolayers (untreated cultures). Thus, the concentration of the essential oil or monoterpenes that inhibited the plaque count by $50 \%$ (inhibitory concentration for $50 \%$ of plaques $=\mathrm{IC}_{50}$ ) was determined from the dose-response curves. The selectivity index (SI) was calculated according to the ratio $\mathrm{CC}_{50} / \mathrm{IC}_{50}$.

The procedures to perform the pre- and posttreatment assays were similar to that described for the virucidal assay. For the pre-treatment assay, the cells were incubated with the MNTC of the essential oil or monoterpenes for $1 \mathrm{~h}$ prior to virus inoculation. After this incubation period, the compound was removed and the virus inoculation was performed as described above. For the post-treatment assay, the essential oil or monoterpenes were added after the virus inoculation and incubated with the cells for a period of $72 \mathrm{~h}$ at $37{ }^{\circ} \mathrm{C}$ and $5 \% \mathrm{CO}_{2}$. Control wells containing MEM with $1 \%$ methanol without the oil or monoterpenes were also included. All results were calculated as the average of three independent experiments performed in duplicate.

\section{Results and Discussion}

The chromatographic analysis of the basil essential oil used to perform the present study was previously described (Pozzatti et al., 2008). The data from the cytoto- xicity and antiviral tests are described in Table 1 and Figures 1,2 and 3 .

The main constituents of the essential oil of Ocimum basilicum used in this study were identified as monoterpenes: 1,8-cineole $(23.61 \%)$, camphor $(12.80 \%)$, and linalool (31.22\%) (Pozzatti et al., 2008). The amount of the

Table 1 - Citotoxicity and antiviral activity of the essential oil of Ocimum basilicum and monoterpenes against BVDV. The results were obtained from the average of three independent experiments performed in duplicate.

\begin{tabular}{lccc}
\hline Essential oil/monoterpene & $\mathrm{CC}_{50}{ }^{\mathrm{a}} \pm \mathrm{SD}^{\mathrm{b}}$ & $\mathrm{IC}_{50}{ }^{\mathrm{c}} \pm \mathrm{SD}$ & $\mathrm{SI}^{\mathrm{d}}$ \\
\hline $\begin{array}{l}\text { Essential oil of Ocimum } \\
\text { basilicum }\end{array}$ & $1750.01 \pm 11.32$ & $474.29 \pm 8.65$ & 3.69 \\
$\begin{array}{l}\text { 1, 8-cineole } \\
\text { Camphor }\end{array}$ & $2996.10 \pm 9.53$ & $331.17 \pm 7.42$ & 9.05 \\
Thymol & $4420.12 \pm 8.89$ & $318.51 \pm 8.57$ & 13.88 \\
\hline
\end{tabular}

${ }^{\mathrm{a} C y t o t o x i c}$ concentration $(\mu \mathrm{g} / \mathrm{mL})$ for $50 \%$ of the cell culture.

${ }^{\mathrm{b}}$ Standard deviation.

${ }^{\mathrm{c}}$ Inhibitory concentration $(\mu \mathrm{g} / \mathrm{mL})$ for $50 \%$, as obtained in the virucidal assay.

${ }^{\mathrm{d}}$ Selectivity index $\left(\mathrm{CC}_{50} / \mathrm{IC}_{50}\right)$.

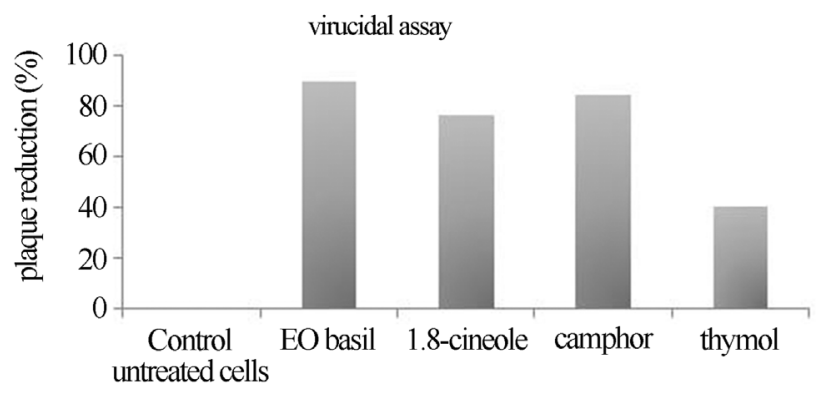

Figure 1 - Antiviral activity of the essential oil (EO) of Ocimum basilicum (basil) and monoterpenes against the bovine viral diarrhea virus (BVDV) in the virucidal assay. The virus was incubated with the MNTCs of the essential oil/ monoterpenes for $1 \mathrm{~h}$ at $25^{\circ} \mathrm{C}$. Readings were performed 3 days after the inoculation by comparison with non-inoculated cells. The results are expressed as the percentages of plaque reduction.

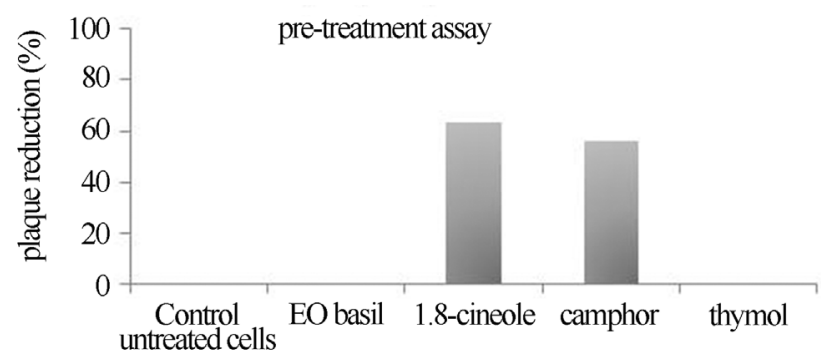

Figure 2 - Antiviral activity of the essential oil (EO) of Ocimum basilicum (basil) and monoterpenes against the bovine viral dirrhea virus (BVDV) after the pre-treatment of cells. The cells were incubated with the MNTCs of the essential oil/ monoterpenes prior to viral infection. Readings were performed 3 days after the inoculation by comparison with non-inoculated cells. The results are expressed as the percentages of plaque reduction. 


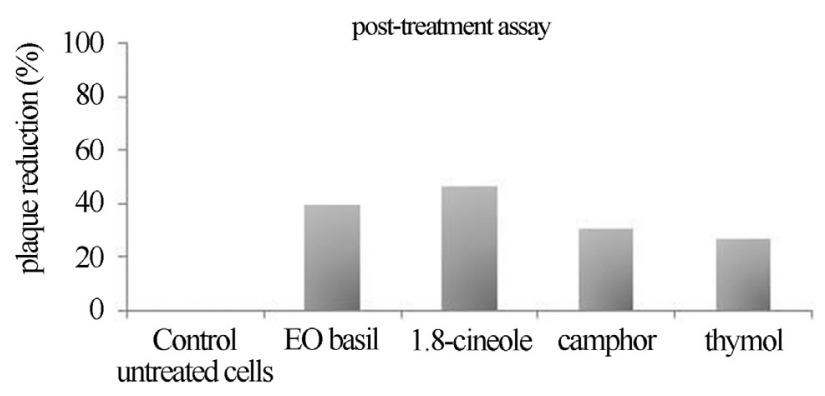

Figure 3 - Antiviral activity of the essential oil (EO) of Ocimum basilicum (basil) and monoterpenes against the bovine viral dirrhea virus (BVDV) after virus inoculation. The MNTCs of the essential oil/ monoterpenes were added to the cells after virus absorption and maintained for $72 \mathrm{~h}$. The readings were then performed by comparison with non-inoculated cells. The results are expressed as the percentages of plaque reduction.

essential oil or compound required to demonstrate a $50 \%$ cytotoxic concentration $\left(\mathrm{CC}_{50}\right)$ was similar, or, in some cases, superior to values described in previous studies using essential oils and constituent compounds. Camphor $\left(\mathrm{CC}_{50}=4420.12 \mu \mathrm{g} \mathrm{mL}{ }^{-1}\right)$ and 1,8-cineole $\left(\mathrm{CC}_{50}=\right.$ $2996.10 \mu \mathrm{g} \mathrm{mL}^{-1}$ ) demonstrated lower toxicities towards the MDBK cells than the essential oil of basil $\left(\mathrm{CC}_{50}=\right.$ $\left.1750.01 \mu \mathrm{g} \mathrm{mL}^{-1}\right)$, while thymol $\left(\mathrm{CC}_{50}=1404.32 \mu \mathrm{g} \mathrm{mL}^{-1}\right)$ was the most toxic of all the products examined (Table 1). The values of $\mathrm{CC}_{50}$ demonstrated for the essential oil of Lippia graveolens (Mexican oregano) and its major constituent, carvacrol, toward the same cell culture have been reported as 568 and $215 \mu \mathrm{g} \mathrm{mL}^{-1}$, respectively (Pilau et al., 2011). Moreover, propolis extracts from two different sources have been shown to cause high toxicity to MDBK cells, exhibiting $\mathrm{CC}_{50}$ values of 293 and $343 \mu \mathrm{g} \mathrm{mL}$ (Cueto et al., 2011).

1,8-cineole has previously been tested for antiviral activity against the herpes simplex virus, exhibiting a $\mathrm{CC}_{50}$ value of $2000 \mu \mathrm{g} \mathrm{mL}^{-1}$ (Astani et al., 2010). In the same study, the $\mathrm{CC}_{50}$ for thymol was $85 \mu \mathrm{g} \mathrm{mL}{ }^{-1}$. It is important to emphasise that the cells utilised to perform these experiments were RC-37 in the referenced study (Astani et al., 2010). Different experimental conditions and the use of diverse cell cultures to perform such experiments may be the reason for the differences observed. However, there are relevant aspects of the studies that should be considered. The cytotoxicities of the monoterpenes, 1,8-cineole and thymol, demonstrated consistency when tested against different cell lines in independent laboratories. Low toxicity to the cell culture is a good initial indicator for an antiviral candidate; thus, the data obtained are promising because the oil and compounds examined in this study demonstrated lower toxicities in almost all of the comparisons.

The parameters for the definition of a compound as a good antiviral candidate are not well defined, showing a great variation among values of $\mathrm{IC}_{50}$ and $\mathrm{SI}$ for different viruses and products. There are numerous variables that in- fluence the final results of a susceptibility test, including cell culture, virus titer, incubation times, concentration of the antiviral compound, reference strains, assay methods, calculations and interpretation criteria (Swierkosz and Hodinka, 1999). However, the basis of our discussion will be a suggestion from Amoros et al. (1992) applied to herpes simplex viruses (HSV), which propose that a selectivity index (SI) greater than four would be appropriate to consider that a compound has a potential antiviral activity.

Following the guidelines cited above, it could generally be concluded that the monoterpenes examined showed antiviral activities towards BVDV (Table 1). In particular, the monoterpenes, camphor $(\mathrm{SI}=13.88)$ and 1,8 -cineole $(\mathrm{SI}=9.05)$ presented the highest SI values in the virucidal assay. On the other hand, the $\mathrm{IC}_{50}$ and $\mathrm{SI}$ of the Ocimum basilicum essential oil were not acceptable, despite the considerable percentage of viral inhibition shown by this essential oil (Table 1).

The antimicrobial activity of the essential oil of $O$. basilicum has partly been attributed to the presence of a high concentration of linalool in tested samples (Suppakul et al., 2003; Sartoratto et al., 2004). The concentration of this monoterpene in the essential oil samples for this study was $31.22 \%$, which may be an insufficient amount to demonstrate expressive antiviral activity. Additionally, camphor was not present in a major concentration in this sample of the essential oil. When analysed separately, camphor and 1,8-cineole exhibited high values of SI, which may suggest the presence of a constituent compound in a minor concentration acting synergistically with these monoterpenes for an antagonistic effect when the essential oil of $O$. basilicum as a whole was examined.

Although the results indicate a high percentage of plaque reduction $(90 \%)$ by the essential oil of $O$. basilicum, the doses needed to inhibit plaque formation $\left(\mathrm{IC}_{50}=474.29\right.$ $\mu \mathrm{g} \mathrm{mL}^{-1}$ ) (Table 1) make it impracticable to use this essential oil as an antiviral therapy. In addition, extracts from this plant did not demonstrate antiviral activity against HCV when examined by protease inhibition experiments in previous work (Hussein et al., 2000). Extracts from the leaves of $O$. basilicum also exhibited low percentages of virus inhibition (59.8\% for the alcoholic extract and 37.6\% for the aqueous extract) in a study that tested different plants commonly used in traditional Sudanese medicine (Hussein et al., 2000). Thus, the evidence indicates that the essential oil and extracts of $O$. basilicum would not have an antiviral effect on $\mathrm{HCV}$; though, further studies are needed. Conversely, the results obtained from the essential oil compounds studied individually indicate antiviral activities.

The infectivity of the BVDV was greatly reduced by the treatment of the virus with the monoterpenes for $1 \mathrm{~h}$ prior to inoculation (Figure 1). At maximum non-toxic concentrations (MNTC), the observed plaque reductions were approximately $84 \%$ for the camphor and $75 \%$ for 1,8 -cineole. The plaque formation by HSV-1 was also reduced 
when the virus was incubated for $1 \mathrm{~h}$ at $37^{\circ} \mathrm{C}$ with 1,8 -cineole (Astani et al., 2010), although the percentage of reduction $(40 \%)$ was considered moderate. In another experiment, 1,8-cineole and camphor reduced the infectivity of HSV -1 by $35 \%$ and $0 \%$, respectively, when used at the dilution of $0.1 \%$ (Sivropoulou et al., 1997). The viruses from the Herpesviridae family are viruses showing an expressive and diverse number of proteins at the envelope (Roizmann et al., 1992), while the Flaviviridae family viruses are relatively smaller showing less diversity in envelope proteins (Ridpath, 2010) than the herpes viruses. These structural differences most likely contributed to the diversity of results observed in this study.

The pre-treatment of cells with the compounds (Figure 2) or the incubation of these compounds with the cells after virus inoculation (Figure 3) did not result in antiviral activities at the same level as the direct treatment of the virus (Figure 1). These results suggest that the investigated compounds acted directly on the viral particle and interfered with viral infectivity. The antimicrobial actions of the essential oils and its main constituents have previously been explained based on their effects on the structure and functions of the bacterial membrane. The activities of these compounds were attributed to their lipophilic characteristics that would allow their interaction with the lipidic membrane of the bacteria (Helander et al., 1998; Cox et al., 2000). A similar effect could be expected with the lipidic viral envelope (Schnitzler et al., 2007). In fact, several essential oils and their major compounds have demonstrated antiviral activities against viruses with a lipidic envelope, suggesting that these compounds inactivated the virus by directly interfering with the viral envelope structures or masking viral structures needed for the absorption and entry to the cell (Schnitzler et al., 2007; Astani et al., 2010).

In general, thymol was the least efficient monoterpene in the antiviral activity tests performed (Figures 1, 2, and 3). In another virucidal assay previously described, this monoterpene inhibited the plaque formation of HSV by $>80 \%$ (Astani et al., 2010). However, the therapeutic index of the compound in that case was only 2.8 due to its high toxicity to the RC-37 cells used to perform the tests.

Studies have demonstrated the potential of medicinal plants for therapeutic applications using the BVDV as a model for the HCV. The analysis of the antiviral effect of artemisina, obtained from the plant Artemisia annua, has suggested a potential use for this compound in association with current therapies for the infections caused by flaviviruses (Romero et al., 2006). Aqueous extracts from Celosia cristata, Ophioglossum vulgatum, Houttuynia cordata, Selaginella tamariscina, Alpinia galanga and Alpinia oxyphylla also inhibited BVDV, while not showing toxic effects on the MDBK cells (Herrmann et al., 2011). In addition, extracts from the roots of Phyllanthus amarus caused a significant reduction in the cytopathic effect of BVDV with a therapeutic index greater than 6 and no cytotoxicity, which has justified a more detailed investigation of a possible action on the HCV (Bhattacharyya et al., 2003).

The comparisons among the indexes already described and obtained from the monoterpenes utilised in the present study indicate potential anti-BVDV activities for camphor and 1,8-cineole (Table 1). The antiviral activities against the BVDV exhibited by the monoterpenes in this study, especially camphor, may suggest that these compounds could have activity on the HCV, since the BVDV virus has been utilised as a model for studies on $\mathrm{HCV}$ (Bhattacharyya et al., 2003; Buckwold et al., 2003; Yanagida et al., 2004; Zhang et al., 2010). However, more studies are needed in order to demonstrate such possibility.

\section{References}

Amoros M, Simões CMO, Girre L, Sauvager F, Cormier M (1992) Synergistic effect of flavones and flavonols against herpes simplex virus type 1 in cell culture. Comparison with the antiviral activity of propolis. J. Nat Prod 55 (12): 1732-1740.

Astani A, Reichling J, Schnitzler P (2010) Comparative study on the antiviral activity of selected monoterpenes derived from essential oils. Phytother Res 24(5):673-679.

Bakkali F, Averbeck S, Averbeck D, Idaomar M (2008) Biological effects of essential oils - A review. Food Chem Toxicol 46(2):446-475.

Bhattacharyya R, Bhattacharya S, Wenzel-Mathers M, Buckwold VE (2003). Phyllanthus amarus root clone with significant activity against bovine viral diarrhoea virus - A surrogate model of hepatitis C virus. Currt Sci India 84(4):529-533.

Botton SA, Da-Silva AM, Brum MCS, Weiblen R, Flores EF (1998) Antigenic characterization of Brazilian bovine viral diarrhea virus isolates by monoclonal antibodies and crossneutralization. Braz J Med Biol Res 31(11):1429-1438.

Buckwold VE, Beer BE, Donis RO (2003) Bovine viral diarrhea virus as a surrogate model of hepatitis $\mathrm{C}$ virus for the evaluation of antiviral agents. Antivir Res 60(1):1-15.

Chiang, LC, NG LT, Cheng PW, Chiang W, Lin CC (2005) Antiviral activities of extracts and selected pure constituents of Ocimum basilicum. Clin Exp Pharmacol 32(10):811-816.

Cox SD, Mann CM, Markham JL, Bell HC, Gustafson JE, Warmington JR, Wyllie SG (2000) The mode of antimicrobial action of the essential oil of Melaleuca alternifolia (Tea tree oil). J. Appl Microbiol 88(1):170-175.

Cueto AP, Alves SH, Pilau M, Weiblen R, Kubiça TF, Lovato LT (2011) Atividade antiviral do extrato de própolis contra o calicivírus felino, adenovírus canino 2 e vírus da diarréia viral bovina. Cienc Rural 41(10):1800-1806.

Helander IM, Alakomi HL, Latva-Kala K, Mattila-Sandholm T, Pol I, Smid EJ, Gorris LGM, Von Wright A (1998) Characterization of the Action of Selected Essential Oil Components on Gram-Negative Bacteria. J. Agr. Food Chem 46(9):3590-3595.

Herrmann F, Romero MR, Blazquez AG, Kaufmann D, Ashour ML, Kahl S, Marin JJG, Efferth T, Wink M (2011) Diversity of pharmacological properties in Chinese and European medicinal plants: Cytotoxicity, antiviral and antitrypanosomal screening of 82 herbal drugs. Diversity 3(4):547-580. 
Hussein G, Miyashiro H, Nakamura N, Hattori M, Kakiuchi N, Shimotohno K (2000) Inhibitory effects of Sudanese medicinal plant extracts on hepatitis $\mathrm{C}$ virus $(\mathrm{HCV})$ protease. Phytother Res 14(7):510-516.

Jassim AS, Naji MA (2003) Novel antiviral agents: A medicinal plant perspective. J Appl Microbiol 95 (3):412-427.

Lee SJ, Umano K, Shibamoto T, Lee KG (2005) Identification of volatile components in basil (Ocimum basilicum L.) and thyme leaves (Thymus vulgaris L.) and their antioxidant properties. Food Chem 91(1):131-137.

Liang TJ, Rehermann B, Seeff LB, Hoofnagle JH (2000) Pathogenesis, natural history, treatment, and prevention of hepatitis C. Ann Intern Med 132(4):296-305.

Mosmann T (1983) Rapid colorimetric assay for cellular growth and survival: Application to proliferation and cytotoxicity assays. J Immunol Methods 65(1-2):55-63.

Pilau M R, Alves SH, Weiblen R, Arenhart S, Cueto AP, Lovato LT (2011) Antiviral activity of the Lippia graveolens (Mexican oregano) essential oil and its main compound carvacrol against human and animal viruses. Braz J Microbiol 42(4):1616-1624.

Pozzatti P, Scheid LA, Spader TB, Athayde ML, Santurio JM, Alves SH (2008) In vitro activity of essential oils extracted from plants used as spices against fluconazole-resistant and fluconazole-susceptible Candida spp. Can J Microbiol 54(11):950-956.

Ridpath JF (2010) Bovine Viral Diarrhea Virus: Global Status. Vet Clin N AM - Food A 26(1):105-121.

Roizmann B, Desrosiers RC, Fleckenstein B, Lopez C, Minson AC, Studdert MJ (1992) The family Herpesviridae: an update. The Herpesvirus Study Group of the International Committee on Taxonomy of Viruses. Arch Virol 123(3-4):425-449.

Romero MR, Serrano MA, Vallejo M, Efferth T, Alvarez M, Marin JJG (2006) Antiviral effect of artemisinin from Artemisia annua against a model member of the Flaviviridae family, the bovine viral diarrhoea virus (BVDV). Planta Med 72(13):1169-1174.

Sartoratto A, Machado ALM, Delarmelina C, Figueira GM, Duarte MCT, Rehder VLG (2004) Composition and antimicrobial activity of essential oils from aromatic plants used in Brazil. Braz J Microbiol 35:275-280.

Schnitzler P, Koch C, Reichling J (2007) Susceptibility of drugresistant clinical herpes simplex virus type 1 strains to essential oils of ginger, thyme, hyssop, and sandalwood. Antimicrob Agents Ch 51(5):1859-1862.

Sivropoulou A, Nikolaou C, Papanikolaou E, Kokkini S, Lanaras T, Arsenakis M (1997) Antimicrobial, Cytotoxic, and Antiviral Activities of Salvia fructicosa Essential Oil. J Agr Food Chem 45:3197-3201.

Suppakul P, Miltz J, Sonneveld K, Bigger SW (2003) Antimicrobial properties of basil and its possible application in food packaging. J Agr Food Chem 51(11):3197-3207.

Swierkosz EM, Hodinka RL (1999) Antiviral agents and susceptibility tests. In: Murray, P.R., Baron, E.J., Jorgensen, J.H., Pfaller, M.A., Yolken, R.H. (eds). Manual of Clinical Microbiology. American Society for Microbiology, Washington, DC, pp 1624-1639.

Thiel HJ, Plagemann PGW, Moennig V (1996) Pestiviruses. In: B.N. Fields, D.M. Knipe, Howley, P.M. (eds). Virology. Lippincott, Philadelphia, pp 1059-1073.

WHO. Hepatitis C Fact sheet $\mathrm{N}^{\circ} 164$. 2012. Available at: http://www.who.int/mediacentre/factsheets/fs164/es/. Acessed 27 September 2012.

Yanagida K, Baba C, Baba M (2004) Inhibition of bovine viral diarrhea virus (BVDV) by mizoribine: Synergistic effect of combination with interferon- $\alpha$. Antivir Res 64(3):195-201.

Zhang N, Liu Z, Han Q, Chen J, Lv Y (2010) Xanthohumol enhances antiviral effect of interferon alpha-2b against bovine viral diarrhea virus, a surrogate of hepatitis $\mathrm{C}$ virus. Phytomedicine 17(5):310-316.

All the content of the journal, except where otherwise noted, is licensed under a Creative Commons License CC BY-NC. 